\title{
The Frequency of Catheter-Related Infections in Children: One-Year Experience
}

\section{Çocuk Hastalarda Kateter Illişkili Enfeksiyon Sıklığı; Bir Yıllık Deneyim}

\author{
Fatih Aygün', Deniz Aygün², Haluk Çokuğraş², Halit Çam', Yıldız Camcıoğlu² \\ ' Division of Pediatric Intensive Care, Department of Pediatric Health and Diseases, Istanbul University School of Cerrahpasa Medicine, Istanbul, Turkey \\ ${ }^{2}$ Division of Pediatric Infectious Diseases, Department of Pediatric Health and Diseases, Istanbul University School of Cerrahpasa Medicine, \\ Istanbul, Turkey
}

\begin{abstract}
Objective: Intravascular catheters are used with increased frequency in intensive care units in the management of children. However, in parallel with the increase in the use of catheters there is also an increase in the frequency of catheter related bloodstream infections. The aim of this study is to evaluate the rate and risk of infections associated with intravascular catheterization.
\end{abstract}

Material and Methods: Between the years 2014-2015 Septembers, in Medical Faculty of Cerrahpasa, University of Istanbul, Pediatric Intensive Care Unit, 105 patients and placed 171 intravascular catheters analyzed retrospectively by the patients' medical records.

Results: 78 of the patients (45.6\%) were female, 93 (54.4\%) were male. Average age of catheter insertion was $4.45 \pm 5.48$ years, ranging between 3 days-228 months. One hundred and fifteen catheters $(67.3 \%)$ were used 7 days or more, the average length of usage was $20.33 \pm$ 38.80 days. One hundred sixty four of 171 catheters (95.9\%) were central venous catheters, seven of them (4\%) were arterial catheters. Fifty one of central venous catheters (31\%) were hemodialysis catheters, three of them were $(1.8 \%)$ tunnelled catheters, $110(67.0 \%)$ of them were central venous pressure catheters. Catheter sepsis were reported in $3.5 \%$, local sepsis were in $2.4 \%$, colonisation were in $1.8 \%$ of central venous catheters. As location had no risk for catheter related infections ( $p>0.05$ ), increased time length for the usage of catheters and total parenteral nutrition treatment via catheter showed a significant increase in infection incidence $(p<0.05)$.
Özet

Giriş: Damar içi kateterler günümüzde çocuk hastaların tedavileri ve izlemleri sırasındaki özellikle de yoğun bakım ünitelerinde gittikçe artan bir sıklıkla kullanılmaktadır. Fakat kateter kullanımındaki artışa paralel olarak kateter ile ilişkili enfeksiyon sıklığında da artış söz konusudur. Çaıışmamızda kateter ile ilişkili enfeksiyon sıklığı ve risklerin değerlendirilmesi amaçlanmıştır.

Gereç ve Yöntemler: İstanbul Üniversitesi Cerrahpaşa Tıp Fakültesi Çocuk Yoğun Bakım Ünitesi'nde Eylül 2014 ile Eylül 2015 tarihleri arasında damar içi kateter yerleştirilen 105 hasta ve 171 adet kateter geriye dönük olarak dosya kayıtları ile incelendi.

Bulgular: Kateterlerin 78 (\%45.6)'i kız, 93 (\%54.4)'ü erkek hastaya takıldı. Ortalama kateter takılma yaşı $4.45 \pm 5.48$ yıl, dağılımı 3 gün-228 ay idi. Yüz on beş (\%67.3) kateterin kalış süresi yedi gün ve üzeriydi, kateterlerin ortalama kalış süresi $20.33 \pm 38.80$ gündü. Toplam 171 kateterin 164 (\%95.9)'ü santral venöz kateter, 7 (\%4.0)'si arter kateteriydi. Santral venöz kateterlerin 51 (\%31.0)'i hemodiyaliz kateteri, 3 (\%1.8)'ü tünelli kateter, 110 (\%67.0) tanesi santral venöz basınç kateteriydi. Venöz kateterler incelendiğinde kateter sepsisi \%3.5, lokal enfeksiyon \%2.4, kolonizasyon \%1.8 oranında bulundu. Kateterin takıldığı bölge enfeksiyon sıklığı açısından anlamlı bir farka neden olmazken ( $p>0.05)$, kateter kalış süresinde uzamanın ve total parenteral nütrisyon uygulamasının enfeksiyon sıklığının anlamlı olarak arttırdığı görüldü $(p<0.05)$.

Sonuç: Çocuk hastaların izleminde önem taşıyan kateterlerin tecrübeli kişiler tarafından yerleştirilmesi, kateter takılması sırasında steril şartla-
Correspondence Address / Yazışma Adresi

Deniz Aygün

İstanbul Üniversitesi Cerrahpaşa Tıp Fakültesi, Çocuk Sağlığı ve Hastalıkları Anabilim Dalı, Çocuk Enfeksiyon Bilim Dalı, İstanbul-Türkiye

E-mail: fdenizaygun@gmail.com OCopyright 2017 by Pediatric
Infectious Diseases Society -Available online at www.cocukenfeksiyon.org ○Telif Hakkı 2017 Çocuk Enfeksiyon Hastalıkları Derneği -Makale metnine www.cocukenfeksiyon.org web sayfasından ulaşılabilir 
Conclusion: The insertion and care of catheters by skilled persons, providing sterile conditions during catheterisation and taking care will reduce the complication rates.

Keywords: Child, intravascular catheter, catheter related bloodstream infections

\section{Introduction}

Catheterization procedures are used very often in intensive care units and in hospital wards due to many interventions such as the follow-up of hemodynamic parameters, vascular access problems, fluid therapy, parenteral nutrition, administration of blood and blood products, and the provision of extracorporeal treatments in children (1-3). As with any interventional procedure, catheterization has its own problems, and perhaps the most important of these are catheter-related infections (CRI) with high mortality and morbidity rates. Infection is often caused around the catheter entry site and junction site. In addition to symptoms of inflammation such as erythema and temperature increase around the catheter, $\mathrm{CRI}$ are defined as being accompanied by systemic findings such as fever and chills (shivering). The most commonly encountered agents are coagulase negative Staphylococci, gram-negative bacilli and Candida albicans $(4,5)$. Many CRIs are known to be preventable when adequate hygienic conditions are provided. In the present study, we investigated whether the use of catheter is reliable when used by experienced individuals, and to emphasize the fact that the rate of infections would significantly be reduced when sterile conditions are provided during catheter care and when effective catheter care is performed.

\section{Materials and Methods}

All catheters which were administered at the Pediatric Intensive Care Unit of Istanbul University, Cerrahpasa Faculty of Medicine between September 2014 and September 2015 were retrospectively reviewed. The age, sex, diagnosis and duration in the intensive care unit of patients with central venous catheter were evaluated. The indications for catheter insertion, insertion site and length of stay, total parenteral nutrition, infection rates, breeding microorganisms, reasons for catheter removal and mortality due to catheter infection were examined retrospectively. We received written approval for the study from the local Ethics Committee, with approval number 326814.

The femoral, internal jugular, and subclavian veins were used for catheter procedures. Our catheters were all with lumen and antibiotic-free. All the catheters were administered by one expert. After sterilizing the catheter insertion site with $10 \%$ povidone iodine during administration, it was left to dry. rın sağlanması ve kateter bakımına özen gösterme ile enfeksiyon oranları azaltılabilmektedir.

Anahtar Kelimeler: Çocuk, damar içi kateter, kateter ilişkili kan akımı enfeksiyonları

During the procedure, sterile gowns, masks and bonnet were worn, and a single-use sterile dressing was used to cover the entire body. All the catheters were inserted using the Seldinger technique. The location of the catheter was confirmed by chest X-Ray, after insertion of the subclavian and jugular catheters. The catheter was covered with sterile gauze on the first day and daily dressing was performed. No local antibiotics were applied to the catheter inlet. Heparin was not used. No lock solution or antibiotic was applied for closure after the procedure. The catheter sets were changed every 24 hours if the catheter sets used lipid-containing liquids, and every 48 hours for other sets.

Culture samples were obtained from patients with a clinical picture of sepsis and laboratory findings during follow-up. Growth of the same microorganism in blood culture samples collected from the catheter and periphery was considered as a catheter-related bloodstream infection and as colonization when there was growth from that collected from the catheter and no growth from the blood cultures collected from the periphery. Detection of erythema, discharge and temperature increase about $2 \mathrm{~cm}$ from the catheter entry site was evaluated as the presence of local infections, and under such conditions the catheters were all removed by a pediatrician under sterile conditions. The catheters were not changed routinely in the absence of a catheter-related infection or luminal obstruction. No catheter-tip culture sample was sent for evaluation unless a catheter-related infection was considered.

\section{Statistical Analysis}

Statistical analysis was performed using the SPSS version 15.0 software (SPSS Inc., Chicago, IL, USA). Quantitative data were expressed in mean \pm standard deviation, while categorical data were expressed in frequency ( $\mathrm{n}$ ) and percentage (\%). The Student's t-test was used for the evaluation of normal distribution of quantitative data, while the Mann-Whitney $\mathrm{U}$ test was used for abnormal distribution and the chi-square test for the evaluation of categorical data. A p value of $<0.05$ was considered statistically significant.

\section{Results}

A total of 171 catheters were administered to 105 patients who were admitted to the pediatric intensive care unit between September 2014 and September 2015. Catheters were administered to our patients due to indications such as vas- 
Table 1. Demographic characteristics of patients

\begin{tabular}{|c|c|}
\hline & $n^{*}(\%)$ \\
\hline $\begin{array}{l}\text { Sex } \\
\quad \text { Female } \\
\text { Male }\end{array}$ & $\begin{array}{l}78(45.6 \%) \\
93(54.4 \%)\end{array}$ \\
\hline $\begin{array}{l}\text { Clinical diagnosis groups } \\
\text { Metabolic } \\
\text { Infectious } \\
\text { Renal failure } \\
\text { Neurological } \\
\text { Hematology-Oncology } \\
\text { Others }\end{array}$ & $\begin{array}{l}43(25.1 \%) \\
31(18.1 \%) \\
25(14.6 \%) \\
19(11.1 \%) \\
16(9.4 \%) \\
37(21.6 \%)\end{array}$ \\
\hline $\begin{array}{l}\text { Reason for insertion } \\
\text { Inability to identify } \\
\text { Vascular access } \\
\text { Hemodialysis } \\
\text { Drug-fluid treatment } \\
\text { Monitorization }\end{array}$ & $\begin{array}{c}77(45.0 \%) \\
53(31.0 \%) \\
34(19.9 \%) \\
7(4.1 \%)\end{array}$ \\
\hline $\begin{array}{l}\text { Type of central venous catheter } \\
\text { inserted } \\
\text { Central venous pressure } \\
\text { Hemodialysis } \\
\text { Tunneled permanent catheter }\end{array}$ & $\begin{array}{l}110(67 \%) \\
51(31 \%) \\
3(1.8 \%)\end{array}$ \\
\hline $\begin{array}{l}\text { Region of insertion } \\
\text { Femoral } \\
\text { Jugular } \\
\text { Subclavian } \\
\text { Radial } \\
\end{array}$ & $\begin{array}{c}98(57.3 \%) \\
48(28.1 \%) \\
22(12.9 \%) \\
3(1.8 \%) \\
\end{array}$ \\
\hline $\begin{array}{l}\text { Mode of insertion } \\
\text { Emergency } \\
\text { Elective }\end{array}$ & $\begin{array}{c}108(63.2 \%) \\
63(36.8 \%)\end{array}$ \\
\hline $\begin{array}{l}\text { Reason for removal } \\
\text { No longer needed } \\
\text { Patient mortality } \\
\text { Prolonged duration } \\
\text { Catheter occlusion } \\
\text { Catheter infection } \\
\text { Other } \\
\end{array}$ & $\begin{array}{c}95(55.6 \%) \\
25(14.6 \%) \\
22(12.9 \%) \\
12(7.0 \%) \\
8(4.7 \%) \\
9(5.3 \%) \\
\end{array}$ \\
\hline $\begin{array}{c}\text { Duration of catheter } \\
7 \text { days and above } \\
\text { Less than } 7 \text { days }\end{array}$ & $\begin{array}{c}115(67.3 \%) \\
56(32.7 \%)\end{array}$ \\
\hline $\begin{array}{l}\text { Department for catheter } \\
\text { monitorization } \\
\text { Intensive care } \\
\text { Hospital ward } \\
\text { Intensive care and ward }\end{array}$ & $\begin{array}{l}107(62.6 \%) \\
34(19.9 \%) \\
30(17.5 \%)\end{array}$ \\
\hline
\end{tabular}

cular access problems, blood and blood product transfusions, provision of total parenteral nutrition, and administration of extracorporeal treatments.

Of the catheters, 78 (45.6\%) were inserted into female patients and 93 (54.4\%) into male patients. Age distributions of the patients ranged from 3 days to 228 months. The mean age of catheter insertion was $4.45 \pm 5.48$ years. Patients weighed between 2.5 and 110 kilograms. Metabolic diseases were di-
Table 2. Distribution of factors in catheter-related blood flow infections

\begin{tabular}{|l|c|}
\hline \multicolumn{2}{|l|}{ Infectious Agents } \\
\hline Staphylococcus epidermidis \\
Campylobacter spp. & 4 \\
Enterobacter cloaca & 2 \\
Escherichia coli & 1 \\
Acinetobacter iwoffii & 1 \\
Klebsiella pneumoniae & 1 \\
Candida albicans & 1 \\
Staphylococcus aureus & 1 \\
\hline * More than one microorganism was observed to have growth in some \\
catheters. \\
\hline
\end{tabular}

agnosed in $43(25.1 \%)$ of the patients (Demographic characteristics of the patient are shown in Table 1).

A total of $164(95.9 \%)$ of the 171 catheters were central venous catheters, while seven (4.0\%) were arterial catheters. Of the central venous catheters, 51 (31.0\%) were hemodialysis catheters, three $(1.8 \%)$ were transurethral catheters, while $110(67.0 \%)$ were central venous pressure catheters. In terms of the site of insertion, 98 catheters (57.3\%) were inserted to the femoral region, 48 catheters ( $28.1 \%$ ) to the jugular and 22 catheters $(12.9 \%)$ were inserted to the subclavian region. One hundred and eight catheters (63.2\%) were administered under emergency conditions. Blood product delivery was performed via 124 catheters (72.5\%). Total parenteral nutrition (TPN) was administered to 13 patients via a catheter.

Catheter-related sepsis was detected in 3.5\% of the 164 catheters, colonization in $1.8 \%$ and local infection in $2.4 \%$ of the catheters. Evaluation of the rates among patients demonstrated that catheter-related sepsis was detected in $5.7 \%$ of patients, colonization in $2.8 \%$ and local infections in $3.8 \%$ of the patients. The number of catheter infections per thousand catheter days was calculated to be 3.38 for patients who were followed up in the hospital wards; this number was 1.88 for patients who were only monitored in the intensive care unit. Two of the patients died due to the catheter-related sepsis. Both patients who died were severely malnourished and were under long-term total parenteral nutrition. Carbapenem-resistant Klebsiella pneumoniae (CR-KP) was detected in one patient and Enterobacter cloacae in the other. All culture growths were in the central venous catheters, and there was no growth in the arterial catheters. Microorganism growth in catheter-associated infections is shown in Table 2.

Ninety-five (55.6\%) of the catheters were removed, as they were no longer deemed useful. One hundred and fifteen catheters (67.3\%) had a stay of 7 days and above, with an average stay of $20.33 \pm 38.80$ days.

There was no significant difference in the incidence of infection when comparing the site of catheter insertion 
Table 3. Comparison of risk factors for catheter infection

\begin{tabular}{|c|c|c|c|c|}
\hline & & \multicolumn{2}{|c|}{ Catheter infection } & \multirow[b]{2}{*}{$\mathbf{p}$} \\
\hline & & Yes $(n=13)$ & No $(n=158)$ & \\
\hline Site of insertion & $\begin{array}{l}\text { Juguler } \\
\text { Femoral } \\
\text { Subclavian } \\
\text { Radial }\end{array}$ & $\begin{array}{l}5 \\
7 \\
1 \\
0\end{array}$ & $\begin{array}{c}43 \\
91 \\
21 \\
3\end{array}$ & 0.194 \\
\hline Blood product transfusion & $\begin{array}{l}\text { Yes } \\
\text { No }\end{array}$ & $\begin{array}{c}10 \\
3\end{array}$ & $\begin{array}{l}114 \\
44\end{array}$ & 0.132 \\
\hline TPN status & $\begin{array}{l}\text { Yes } \\
\text { No }\end{array}$ & $\begin{array}{l}4 \\
9\end{array}$ & $\begin{array}{c}3 \\
155 \\
\end{array}$ & 0.000 \\
\hline Duration of catheter & $\begin{array}{l}<7 \text { days } \\
\geq 7 \text { days }\end{array}$ & $\begin{array}{c}1 \\
12\end{array}$ & $\begin{array}{c}55 \\
103\end{array}$ & 0.001 \\
\hline Hospital ward with catheter infection & $\begin{array}{l}\text { Intensive care } \\
\text { Pediatric ward } \\
\text { IC + ward }\end{array}$ & $\begin{array}{c}2 \\
11 \\
0\end{array}$ & $\begin{array}{c}105 \\
23 \\
30\end{array}$ & 0.008 \\
\hline
\end{tabular}

( $p>0.05$ ). The incidence of infection was found to increase significantly as the length of catheter-stay was prolonged ( $p=$ 0.001). Although TPN administration significantly increased the risk of infection $(p=0.000)$, blood product transfusion was not found to be associated with infection $(p=0.132)$. The incidence of infection was found to be significantly high with catheters monitored in the hospital wards $(p=0.008)$. Comparisons of risk factors for catheter infection are shown in Table 3.

\section{Discussion}

The successful application of catheterization in adult patients has led to its increased usage due to the advantages it has on children. An intravenous catheter is reported to be placed in $6 \%$ of patients admitted to the hospital (6). A safe intravenous route is of great importance in the management of critical patients in pediatric intensive care units and in patients with long-term hospital admissions. Moreover, the stress posed by the difficulty of finding an intravenous route during catheter placement, on health workers, the child and the family is eliminated. Although it is reliable when performed by experienced individuals, intravenous catheterization has its own complications as it is with every medical intervention. Catheter-related infections (CRI) are one of the most serious of these complications.

Catheter-related bloodstream infections, which are a substantial cause of morbidity and mortality, and which increase hospital stay and the costs of care, can be prevented with simple methods. Many guidelines have been published for the prevention of CRIs. The most important of these were those published in 2009 by the Infectious Diseases Society of America (IDSA) and in 2011 by the Centers for Disease Control and Prevention (CDC). In these guidelines, five basic rules called 'central road package' are emphasized $(7,8)$. Washing of hands, personnel training, skin antiseptics, provision of barrier methods, daily evaluation of the catheters and removal of the catheter when no longer needed are the most important practices to be considered. Studies conducted in pediatric intensive care units demonstrate that in-staff training courses emphasized the reduced rates of infection $(9,10)$. Particular attention has been paid to this rule during catheter set up and care in our unit.

Risk factors related to the catheter, host and hospital team have been reported for the development of catheter-related infection. The effect of substances used to make catheters, on the infections is also known. In vitro studies have demonstrated that polyurethane and Teflon catheters have lesser risk of infection than polyethylene and polyvinyl catheters, and that polyurethane catheters are more resistant, particularly due to the sticky nature of microorganisms on the catheters (11). Polyurethane catheters were used in all of our patients.

Cleaning of the catheter insertion area is also another important condition to be considered. Antiseptic products used include chlorhexidine, povidone iodine, and $70 \%$ alcohol (7). Although it has recently been reported that chlorhexidine has a very strong attachment affinity to skin proteins and that its antimicrobial effect on the skin lasts for 48 hours, there are reservations for its use particularly in infants less than two months of age. In our unit, $10 \%$ povidone iodine was used during the catheterization procedure. Transparent polyurethane or chlorhexidine-impregnated dressings are among the most preferred methods for preventing catheter-related bloodstream infections in intensive care units; however, the use of these products is also known not to reduce the rate of infection. In a study by Hatler et al. in which two dressings were compared, no significant difference was found with regards to the risk of developing infection (12). Catheter placement in our unit was performed 
using aseptic techniques and the same care was taken for its management; the entrance points were checked. Dressings were changed daily if the catheters were dressed using sterile gauze. However, catheter care is performed weekly if a dressing with transparent polyurethane and a chlorhexidine gel in the middle is used, as long as the integrity of the dressing remains intact.

The risk of infection development was also thought to be affected by catheter site; in particular the rate is suggested to be higher in the femoral region due to the risk of urinary and fecal contamination; however, recent studies have reported no difference between the femoral and subclavian regions in terms of infection (13). In our study, no significant relationship was also detected between catheter site and the risk of infection.

Review of the literature have demonstrated that the risk of developing infection increases as duration of the catheter is prolonged $(6,7,14,15)$. In the study conducted by Mclaws et al. the incidence of infection among the catheters that have been in place for about 1-5 days was reported as 2.1 per 1000 catheter days, and about 10.2 for catheters of 16-30 days duration (16). However, in the Cochrane analysis published in 2015, it was suggested that regular replacement of catheters every 72-96 hours did not reduce catheter-related complications, but recommended that catheters could only be changed when clinically necessary (17). Nevertheless, catheter duration of over 21 days is one of the most significant risk factors for the increase in catheter-related infections. In our study, it was also observed that the incidence of infection significantly increased as the length of catheter-stay prolonged.

The use of catheter for total parenteral nutrition (TPN) and blood transfusion, the presence of chronic metabolic disorder in the patient, and recurrent catheterization are the major risk factors which increase catheter-related infections $(14,15)$. In our study, there was also no statistically significant difference between catheter blood product delivery and catheter infection, as the vast majority of patients had blood product transfusions. Patients receiving TPN were observed to have a higher incidence of catheter-related infection.

To identify CRIs, culture samples should be collected from both the periphery and the entire lumen of the catheter; catheter-tip culture sampling should be performed in cases where catheter removal is required. It should be, particularly, noted that the first blood sample obtained when a culture sample is collected from the catheter must be cultured in the culture bottle. Culture growth in the blood culture obtained is a $66 \%$ indication for $\mathrm{CRI}$, and a negative culture has a $97 \%$ exclusion rate for infection $(18,19)$. Although interpretation of cultures is more important with quantitative culture samples obtained from catheters and the periphery, quantitative blood culture sampling is not performed in many centers.
In the assessment of bacteremia, it is important to determine the risk of infection by calculating the number of catheter-related infections per 1000 catheter days (20). In studies conducted on pediatric patients, catheter-related infections were reported in the range of 0.5 to 2.8 per 1000 catheter days (6). In our study, similarly to literature studies, the number of catheter infections per 1000 catheter days in patients of hospital wards was found to be 3.38 , whereas this rate was only 1.88 in patients of the intensive care unit. We suggested that this difference is due to the fact that the intensive care nurses and staff have received training on catheter care follow-ups.

Catheter-related sepsis was detected in $5.7 \%$ of the 105 patients, colonization in $2.8 \%$ and local infections in $3.8 \%$ of the patients. The most frequent microbiological agents detected in CRIs are gram-positive cocci (the coagulase negative staphylococcus, Staphylococcus aureus). Staphylococci are known to be protected from antibiotics by covering the catheter with its biofilm property made from exopolysaccharides. Gram-negative agents and fungi are also commonly observed infectious agents $(19,21)$. Staphylococcus epidermidis was the most commonly cultured microorganism in our patients, while two of our patients died due to carbapenem-resistant Klebsiella pneumoniae and Enterobacter cloacae. The first patient's catheter infection was on subclavian catheter on the $48^{\text {th }}$ day and the other on the femoral catheter on the $10^{\text {th }}$ day. In addition, there was catheter removal in eight of our patients due to catheter infection (4.7\%).

Catheters should be removed and the proper systemic antibiotics should be administered in the treatment of infection. In our intensive care unit, routine changing of the catheter was not performed, no closure with antibiotic or lock solution was performed; however, the catheter was changed if any complication developed.

In conclusion, in the present study, we showed with our experience of the past one year that the use of intravenous catheter in the pediatric age group by experienced physicians and nurses would decrease catheter-related infections. However, we believe further prospective, large-scale studies are needed need to confirm these findings.

Ethics Committe Approval: Ethics committee approval was received for this study from Istanbul University Cerrahpasa Medical Faculty's local ethics committee.

Informed Consent: Written informed consent was received from patients.

Peer-review: Externally peer-reviewed.

Author Contributions: Concept-HÇ, HÇ, YC; Design-FA, DA, HÇ; Data collection and/or Proccessing-FA, DA; Analysis and/or InterpretationFA, DA, YC; Critical Review-HÇ, HÇ, YÇ 
Conflict of Interest: No conflict of interest was declared by the authors.

Financial Disclosure: The authors declared that this study has received no financial support.

\section{References}

1. Cotogni P, Pittiruti M. Focus on peripherally inserted central catheters in critically ill patients. World J Crit Care Med 2014;4:80-94. [CrossRef]

2. Akyıldız B, Kondolot $M$, Akçakuş $M$ ve ark. Çocuk yoğun bakım ünitesinde santral venöz kateterizasyon uygulanan hastalarımızın değerlendirilmesi: iki yıllık deneyimlerimiz. Çocuk Sağlığı ve Hastalıkları Dergisi 2009;52:63-7. [CrossRef]

3. Schexnayder SM, Storm EA, Stroud MH, Moss MM, Ross AS, Fiser RT, et al. Pediatric vascular access and centeses. In: Fuhrman BP, Zimmerman JJ (eds). Pediatric critical care. Philadelphia: Elsevier, 2011:139-63.

4. Fagan RP, Edwards JR, Park BJ, Fridkin SK, Magill SS. Incidence trends in pathogen-specific central line-associated bloodstream infections in US intensive care units, 1990-2010. Infect Control Hosp Epidemiol 2013;34:893-9. [CrossRef]

5. Mermel LA, Farr BM, Sheretz RJ, et al. Guidelines for the management of intravascular carheter-related infections. Clin Infect Dis 2001;32:124972. [CrossRef]

6. Maki DG, Kluger DM, Crnish CJ. The risk of bloodstream infection in adults with different intravascular devices: a systematic review of 200 published prospective studies. Mayo Clin Proc 2006;81:1159-71. [CrossRef]

7. O'Grady NP, Alexander M, Burns LA, et al; Healthcare Infection Control Practices Advisory Committee. Guidelines for the prevention of intravascular catheter-related infections. Am JInfect Control 2011;39:(4 Suppl 1):S1-34. [CrossRef]

8. Mermel LA, Allon M, Bouza E, et al. Clinical practice guidelines for the diagnosis and management of intravascular catheter-related infection: 2009 Update by the Infectious Diseases Society of America. Clin Infect Dis 2009:1;49:1-45. No abstract available. Erratum in: Clin Infect Dis 2010 Feb 1;50:457. Clin Infect Dis 2010;50:1079. [CrossRef]

9. Chuengchitraks S, Sirithangkul S, Staworn D, Laohapand C. Impact of new practice guideline to prevent catheter related blood stream infection (CRBSI): experience at the Pediatric Intensive Care Unit of Phramongkutklao Hospital. J Med Assoc Thai 2010;(Suppl 6):S79-83. [CrossRef]
10. Abramczyk ML, Carvalho WB, Medeiros EA. Preventing catheterassociated infections in the Pediatric Intensive Care Unit: impact of an educational program surveying policies for insertion and care of central venous catheters in a Brazilian teaching hospital. Braz J Infect Dis 2011;15:573-7. [CrossRef]

11. O'Grady NP, Alexander $M$, Dellinger $E P$, et al. Guidelines for the prevention of intravascular catheter-related infections. CID 2002; 35:1281-307.

12. Hatler C, Buckwald L, Salas-Allison Z, Murphy-Taylor C. Evaluating central venous catheter care in a pediatric intensive care unit. Am J Crit Care 2009;18:514-20; quiz 521. [CrossRef]

13. Reyes JA, Habash ML, Taylor RP. Femoral central venous catheters are not associated with higher rates of infection in the pediatric critical care population. Am J Infect Control 2012;40:43-7. [CrossRef]

14. Karapınar B, Cura A. Complications of central venous catheterization in criti-cally ill children. Ped Int 2007;49:593-9. [CrossRef]

15. Anıl AB, Anıl M, Kanar B, et al. The evaluation of central venous catheterization complications in a pediatric intensive care unit. Turk Arch Ped 2011;46:215-9. [CrossRef]

16. Mclaws ML, Berry G. Nonuniform risk of bloodstream infection with increasing central venous catheter-days. Infect Control Hosp Epidemiol 2005;26:715-9. [CrossRef]

17. Webster J, Osborne S, Rickard CM, New K. Clinically-indicated replacement versus routine replacement of peripheral venous catheters. Cochrane Database Syst Rev 2015;8:CD007798.14. [CrossRef]

18. Kebudi R, Devecioğlu Ö, Gürler N. Pediatrik febril nötropeni kılavuzu: Tanımlar ve tanı yöntemleri. FLORA 2004;9:73-105. [CrossRef]

19. Öztürk R. Kateter enfeksiyonlarında klinik, tanı ve tedavi. ANKEM Derg 2000;14:460-7. [CrossRef]

20. Tokars Jl, Klevens M, Edwards JR, Horan TC. Measurement of the impact of risk adjustment for central line-days on interpretation of central lineassociated blo-odstream infection rates. Infect Control Hosp Epidemiol 2007;28:1025-9. [CrossRef]

21. Goldmann DA, Pier GB. Pathogenesis of infections related to intravascular catheterization. Clin Microbiol Rev 1993;6:176-92. [CrossRef] 